Berkala Ilmu Perpustakaan dan Informasi, Vol. 14, No. 1, Juni 2018, Hal. 1-10 DOI: $10.22146 /$ bip.33315

ISSN 1693-7740 (Print), ISSN 2477-0361 (Online)

Tersedia online di https://jurnal.ugm.ac.id/bip

\title{
Model literasi budaya masyarakat Tatar Karang di Kecamatan Cipatujah Kabupaten Tasikmalaya
}

\author{
Encang Saepudin ${ }^{1}$, Ninis Agustini Damayani ${ }^{1}$, Agus Rusmana ${ }^{1}$ \\ ${ }^{1}$ Prodi Ilmu Perpustakaan, Fakultas Ilmu Komunikasi, Universitas Padjadjaran \\ Email: encang@unpad.ac.id
}

Naskah diterima: 19 Februari 2018, direvisi: 6 Maret 2018, disetujui: 9 Mei 2018

\begin{abstract}
ABSTRAK
Pendahuluan. Belum dimilikinya strategi yang tepat dalam pengembangan budaya, menjadi salah satu sebab lemahnya budaya Sunda dalam mempertahankan daya dan mutu hidupnya. Dengan demikian, diperlukan adanya strategi pengembangan kebudayaan yang tepat dan teruji. Strategi ini harus disusun dan dibangun bersama berdasarkan prinsip-prinsip strategis dan berkeadilan. Penelitian ini bertujuan untuk membuat model literasi sebagai bagian dari pelestarian budaya.

Metode penelitian. Peneliti menggunakan metode deskriptif dengan pendekatan studi kasus. Pengumpulan data dilakukan melalui observasi partisipatif, wawancara mendalam, dan dokumentasi untuk sumber data yang sama. Responden dalam penelitian ini yaitu para pengelola Saung Budaya Tatar Karang Cipatujah, tokoh masyarakat, tokoh agama, dan pemerintahan yang berjumlah 13 orang.

Data analisis. Analisis data dilakukan dengan triangulasi teknik. Proses analisis data dilakukan melalui tahapan reduksi, display, dan penarikan kesimpulan/verifikasi.

Hasil dan Pembahasan. Hasil penelitian menunjukkan bahwa model literasi budaya yang dikembangkan di daerah Sindangkerta berdasarkan Culture Experience dan Culture Knowledge dengan prinsip hidup silih asih, silih asah, dan silih asuh. Pengembangan literasi melalui Culture Experience dengan melaksanakan pementasan seni, budaya, dan berbagai ritual, sedangkan pengembangan literasi melalui Culture Knowledge dengan membangun taman bacaan masyarakat.

Kesimpulan dan Saran. Dari hasil penelitian dapat disimpulkan bahwa model literasi budaya sudah bisa membangun kesadaran masyarakat dalam melestarikan budaya Sunda. Selanjutnya disarankan agar dilakukan penelitian untuk menguji efektivitas penerapan model literasi budaya berdasarkan pada partisipasi masyarakat.
\end{abstract}

Kata kunci: Model Literasi; Literasi Budaya; Budaya

\section{ABSTRACT}

Introduction. Limited strategy in the development of culture, become one of the weakness of Sundanese culture in quality of cultural. Thus, it is necessary to have a proper strategy of cultural development. This strategy should be developed on the basis of equity. This study aims to create a literacy model as part of cultural preservation.

Data Collection Method. The study used descriptive method with a case study approach. The collecting data was conducted by using participatory observation, in-depth interviews. Our respondents werel 3 persons in total, consisting of managers of Saung Budaya Tatar Karang Cipatujah, community leaders, religious figures, and government representatives.

Data Analysis. The data was analyzed using triangulation techniques through several stages; reduction, data display, and conclusion drawing/verification.

Results and Discussions. The results showed that the cultural literacy model developed in Sindangkerta area were based on Culture Experience and Culture Knowledge with the principles of mutual care, mutual education, and mutual guidance. Literacy development through Culture Experience was implemented by performing artistic, cultural, and ritual performances, while developing literacy through Culture Knowledge was created by building community reading places. 
Conclusions. The results concluded that the cultural literacy model has been able to build public awareness in preserving Sundanese culture. Further studies are suggested to test the effectiveness of cultural literacy models based on community participation.

Keywords: Literacy Model; Cultural Literacy; Culture

\section{A. PENDAHULUAN}

Budaya Sunda dalam mempertahankan daya dan mutu budaya masih lemah, hal ini dikarenakan belum memiliki strategi yang tepat.

Untuk itu diperlukan strategi pengembangan kebudayaan yang tepat dan teruji. Strategi ini harus disusun dan dibangun bersama berdasarkan prinsip-prinsip strategis dan berkeadilan. Strategi yang tepat dan telah teruji, mampu mengembangkan budaya Sunda bisa lebih bertahan dari terpaan budaya luar.

Strategi pengembangan budaya Sunda perlu penegasan, khususnya mengenai konsep pelestarian budaya. Pelestarian budaya dilakukan sebagai usaha untuk mempertahankan eksistensi budaya dihadapan para generasi muda sebagai penerus tatanan nilainilai luhur budaya. Proses pelestarian budaya bisa dilakukan dengan transfer pengetahuan dari para tokoh budaya atau budayawan kepada para generasi penerus. Proses transfer kebudayaan dapat dilakukan melalui model konversi pengetahuan yakni proses sosialisasi, proses eksternalisasi, proses kombinasi, dan proses internalisasi (Nonaka, 1998). Melalui model konversi pengetahuan ini diharapkan masyarakat yang memiliki pengetahuan bersifat tacit dapat mengembangkan pengetahuannya menjadi pengetahuan explicit. Dengan demikian diharapkan budaya terus berkembang sejalan dengan kehidupan masyarakat pemilik kebudayaan baik secara sosial, politik, maupun ekonomi. Apabila proses transfer pengetahuan budaya dapat dilakukan secara berkelanjutan maka akan terbangun masyarakat yang melek pengetahuan budaya bahkan bisa membangun masyarakat yang melek informasi budaya.

Literasi Informasi bisa dimaknai sebagai melek informasi bahkan sering disebut sebagai keberinformasian (Bahtar \& Sasmita, 2009) dan (Sudarsono, 1997). Literasi informasi merupakan kemampuan dalam pencarian informasi sebagai sumber pengetahuan. Proses pengembangan pengetahuan dimulai dengan kesadaran akan kebutuhan informasi, mengetahui keberadaan informasi yang dibutuhkan. Dan kemampuan melakukan pencarian informasi secara cepat, akurat, dan arif dalam mengomunikasikan serta menggunakan informasi yang diperoleh. Komisi literasi informasi American Library Association (ALA) dalam laporan akhirnya pada tahun 1989 menyimpulkan bahwa :

"Information literate people are those who have learned how to learn. They know how to learn because they know how knowledge is organized, how to find information and how to use information in such a way that others can learn from them. They are people prepared for lifelong learning, because they can always find the information needed for any task or decision at hand.(American Library Association, 1989)"

Berdasarkan hal tersebut, literasi informasi terutama literasi budaya sangat dibutuhkan untuk memiliki kemampuan dalam menggali informasi yang terkandung di dalam berbagai unsur budaya. Pengembangan literasi budaya diperlukan sebagai dasar untuk pengenalan budaya dan proses pembelajaran budaya terhadap masyarakat. Dengan pengembangan literasi budaya, akan terbangun generasi penerus yang memiliki jiwa dan karakter sesuai dengan nilai-nilai budaya bangsa. Hal ini terjadi karena generasi penerus akan memahami nilainilai luhur budaya bangsa. Hal tersebut sejalan dengan batasan literasi budaya yang ada dalam buku pedoman Literasi Budaya dan Kewargaan disebutkan bahwa "Literasi budaya merupakan kemampuan dalam memahami dan bersikap terhadap kebudayaan Indonesia sebagai identitas bangsa." (Kementrian Pendidikan dan Kebudayaan, 2017)"

Berdasarkan kepada batasan literasi budaya maka kegiatan literasi merupakan cermin dari kebudayaan. Dalam hal ini kegiatan literasi 
dapat dijadikan sebagai sarana menyebarluaskan dan pewarisan budaya. Generasi muda harus mengenal dan melestarikan budaya daerah sendiri dalam rangka memperkuat dan melestarikan budaya nasional. Pelestarian norma bangsa merupakan usaha untuk mempertahankan nilai budaya. Oleh karena itu, tujuan dilakukannya pelestarian budaya adalah untuk penguatan nilai-nilai budaya dalam diri bangsa.

Sejalan dengan konsep literasi sebagai bentuk pelestarian budaya, masyarakat Tatar Karang Cipatujah menjalankan proses berbagi pengetahuan budaya dengan konsep silih asih, silih asah dan silih asuh. Untuk menjalankan literasi budaya masyarakat Tatar Karang membangun komunitas Saung Budaya Tatar Karang Cipatujah. Proses berbagi pengetahuan dilaksanakan sesuai dengan filosofi silih asih, silih asah dan silih asuh. Selain itu, dilaksanakan pula pelestarian budaya melalui (1) Culture Experience dan (2) Culture Knowledge. Culture Experience merupakan bentuk pelestarian kebudayaan yang dilaksanakan melalui terjun langsung ke dalam sebuah pengalaman kultural. Dalam hal ini terjadi pelibatan masyarakat secara langsung dalam konteks pelestarian budaya. Culture Knowledge merupakan pelestarian budaya melalui pembangunan pusat pembelajaran atau pusat informasi mengenai berbagai budaya. Pembagunan pusat belajar bertujuan untuk penunjang proses pendidikan bagi pengembangan budaya di samping sebagai potensi pariwisata. Berdasarkan latar belakang di atas, penelitian ini bertujuan menyusun model literasi sebagai upaya pelestarian budaya. Penyusunan model literasi budaya perlu dilakukan agar para pelaku budaya memiliki pedoman bersama dalam pengembangan dan pelestarian budaya. Model literasi disusun dan dibangun bersama berdasarkan prinsip-prinsip strategis dan berkeadilan. Hasil penelitian bersifat original karena berdasarkan kepada data dan fakta hasil penelitian lapangan.

\section{B. TINJAUAN PUSTAKA}

Pada awalnya literasi memiliki cakupan yang sederhana, namun sekarang telah mengalami perkembangan. Pada awalnya literasi hanya berarti melek huruf, artinya orang yang literate adalah mampu membaca. Kemudian pengertian literasi berkembang menjadi pengetahuan dan kemampuan pada sebuah bidang tertentu. Perkembangan cakupan literasi dipengaruhi oleh perkembangan teknologi informasi dan komunikasi. Sebagai gambaran dari evolusi konsep literasi dapat dilihat dari kegiatan membaca. Pada awalnya kegiatan membaca, menulis, dan berhitung bisa disebut sebagai kegiatan memandang halaman buku/kertas. Terdorong oleh perkembangan teknologi komunikasi dan informasi maka kegiatan itu bergeser menjadi kegiatan memandang layar komputer atau layar telepon genggam.

Perkembangan konsep Literasi Informasi, berawal dari usulan Paul Zurkowski, presiden Information Industry Association (IIA) dalam proposalnya kepada National Commission for Library and Information Science (NCLIS) pada tahun 1974. Dia mengusulkan gagasan bahwa seseorang harus memiliki kemampuan mengenali kebutuhan informasi, kemampuan menelusur dan menemukan informasi dan menggunakan informasi dan kemudian mengkomunikasikan pengalamannya ketika menggunakan informasi. Perkembangan selanjutnya terjadi pada 2006 The International Federation of Library Associations and Institutions (IFLA) menerbitkan The International Guidelines on Information Literacy. Pada tahun itu ditentukan standar literasi pada setiap kemampuan. Pustakawan di Indonesia mengenal pedoman IFLA belajar konsep dan teknik Literasi Informasi.

Perkembangan teknologi informasi sangat berperan dalam penyediaan informasi bagi masyarakat. Bahkan dapat dikatakan, era sekarang merupakan era banjirnya informasi. Hal ini dapat dilihat dari melimpahnya informasi yang mudah diakses tanpa dibatasi oleh ruang dan waktu. Melimpahnya informasi ini menuntut masyarakat memiliki kemampuan memilih dan memilah informasi yang diperolehnya, sehingga masyarakat dapat menggunakan informasi secara arif dan sesuai kebutuhannya. 
Literasi merupakan cermin kebudayaan, manusia yang literer dapat disebut sebagai manusia yang berbudaya. Kegiatan literasi dapat digunakan sebagai sarana menyebarluaskan budaya. Literasi jangan hanya diidentikkan dengan baca dan tulis, tetapi juga literasi budaya. Generasi muda harus mengenal dan melestarikan budaya daerah sendiri dalam rangka memperkuat dan melestarikan budaya nasional. Pelestarian norma bangsa merupakan usaha untuk mempertahankan nilai budaya. Tujuan dilakukannya pelestarian budaya yaitu untuk penguatan nilai-nilai budaya dalam diri bangsa. Kajian yang dilakukan oleh Rully K. Anwar (Anwar, 2015), Sri Ati (Ati, 2015) menunjukkan bahwa literasi informasi akan mendorong untuk mengambil keputusan lebih tepat. Sementara itu kajian yang dilakukan oleh Khadijah (2016) menunjukkan bahwa literasi informasi mendorong orang untuk mampu merumuskan, menemukan dan menyimpan informasi dengan cara yang tepat.

Suatu budaya pasti mengalami perubahan sebagai akibat perkembangan zaman. Oleh karena itu, masyarakat sebagai pemilik unsurunsur budaya harus mempertimbangkan unsur kebudayaan mana yang harus dijaga keutuhannya untuk dilestarikan dan unsur budaya yang dapat berubah. Namun, perubahan pada unsur budaya diusahakan tidak terlalu dirasakan oleh pemiliknya (Widja, 1993). Dalam hal ini terjadinya perubahan atau perkembangan dari salah satu unsur budaya harus dilakukan secara bertahap dan eksistensi pendukung kebudayaan tidak hilang. Apabila eksistensi pendukung kebudayaan hilang akan berimplikasi pada kehilangan identitas cultural.

Berdasarkan konsep di atas, sebuah budaya dapat dilestarikan melalui (1) Culture Experience dan (2) Culture Knowledge. Culture Experience merupakan bentuk pelestarian kebudayaan yang dilaksanakan melalui terjun langsung ke dalam sebuah pengalaman kultural. Terjadi pelibatan masyarakat secara langsung dalam konteks pelestarian budaya. Culture Knowledge merupakan pelestarian budaya melalui pembangunan pusat pembelajaran atau pusat informasi mengenai berbagai budaya. Pembangunan pusat belajar bertujuan untuk penunjang proses pendidikan untuk kepentingan pengembangan budaya disamping sebagai potensi pariwisata

\section{METODE PENELITIAN}

Pada pelaksanaan penelitian ini, peneliti memakai metode deskriptif dan fokus pada studi kasus. Melalui pendekatan deskriptif peneliti akan mengilustrasikan rincian-rincian spesifik mengenai keadaan, lokasi, relasi sosial yang berlangsung pada subyek penelitian. Melalui studi kasus peneliti akan memaparkan dan mengilustrasikan secara komprehensif mengenai gambaran individu, kelompok, dan masyarakat" (Mulyana, 2007). Pemilihan pendekatan kasus dengan pertimbangan bahwa sifat data dari studi kasus yaitu mampu mempertahankan keutuhan dari obyek, artinya berbagai data yang berkaitan dengan penelitian studi kasus dipahami sebagai satu kesatuan yang terintegrasi.

Melalui metode studi kasus, pemaparan hasil penelitian didasarkan kepada fakta yang diperoleh selama penelitian berlangsung. Pembahasan hasil penelitian dilakukan secara deskriptif berdasarkan pada data kualitatif hasil wawancara, observasi di lokasi penelitian, dan studi pustaka. Alasan peneliti menggunakan studi kasus karena tujuan dari pelaksanaan studi kasus yaitu untuk menggambarkan hal yang unik, kasus yang memiliki kepentingan yang tidak biasa dalam dirinya, dan perlu dideskripsikan atau diperinci, yang biasa disebut kasus intrinsik(Creswell, 2014). Peneliti meyakini bahwa proses literasi informasi budaya perlu dideskripsikan dan diperinci lebih dalam. Mengingat pengembangan literasi budaya diperlukan sebagai dasar untuk pengenalan budaya dan proses pembelajaran budaya terhadap masyarakat. Dengan pengembangan literasi budaya, akan terbangun generasi penerus yang memiliki jiwa dan karakter sesuai dengan nilai-nilai budaya bangsa.

Peneliti menggunakan teknik triangulasi dalam proses pengumpulan data penelitian. Proses pengumpulan data melalui triangulasi teknik dan sumber. Peneliti melakukan observasi, wawancara mendalam, dan 
dokumentasi untuk sumber data yang sama secara serempak. Peneliti melakukan pengumpulan data melalui triangulasi, ini berarti peneliti mengumpulkan data sekaligus menguji kredibilitas data, yaitu mengecek kredibilitas data dengan berbagai teknik pengumpulan data dan berbagai sumber" (Sugiyono, 2010). Responden dalam penelitian ini adalah 6 orang pengelola Saung Budaya Tatarkarang Cipatujah, 2 orang tokoh masyarakat, 1 orang tokoh agama, dan 4 orang pemerintahan.

\section{HASIL DAN PEMBAHASAN Pelestarian Budaya Sebagai Bentuk Literasi Informasi}

Pemeliharaan budaya Sunda memerlukan proses yang cukup panjang dan rumit. Pengembangan kesadaran masyarakat sebagai pemilik budaya menjadi faktor penentu dalam pelestarian budaya. Pihak-pihak yang memiliki pengetahuan mengenani budaya Sunda memiliki kesadaran untuk mau berbagi pengetahuan, pengalaman, dan keahliannya dengan masyarakat lain terutama generasi muda. Proses berbagi pengetahuan merupakan hal penting dalam mendorong masyarakat untuk menyadari potensi budaya sebagai identitas diri dan bangsanya. Proses ini sering disebut sebagai proses pewarisan budaya.

Proses pewarisan budaya yang dilaksanakan oleh pengelola Saung Budaya Tatar Karang Cipatujah terbagi dalam pelestarian budaya melalui (1) Culture Experience dan (2) Culture Knowledge. Culture Experience merupakan bentuk pelestarian kebudayaan yang dilaksanakan melalui terjun langsung ke dalam sebuah pengalaman kultural. Dalam hal ini terjadi pelibatan masyarakat secara langsung dalam konteks pelestarian budaya. Culture Knowledge merupakan pelestarian budaya melalui pembangunan pusat pembelajaran mengenai berbagai budaya. Pembagunan pusat belajar bertujuan untuk proses pendidikan demi kepentingan pengembangan kebudayaan disamping sebagi potensi pariwisata (Kusumadara, 2011).

Berdasarkan kepada data hasil penelitian proses pelestarian budaya di desa Cipatujah sebagai bentuk literasi budaya dapat digambarkan dalam model literasi pada gambar 1. Pembuatan model ini bertujuan untuk mempermudah pelaksanaan literasi budaya. Hal ini sejalan dengan pendapat Yudistira, bahwa model literasi dibuat sebagai acuan pelaksanaan literasi informasi di sebuah perpustakaan. Dengan adanya model maka tahapan literasi informasi menjadi lebih jelas.(Yudistira, 2015)

Pada gambar 1 memperlihatkan proses pengembangan literasi budaya yang dikembangkan di daerah Sindangkerta berdasar pada filosofi orang sunda yakni silih asih, silih asah, dan silih asuh. Pelaksanaan ketiga konsep ini harus selalu berurutan. Dalam hal ini ketiga konsep ini tidak bisa dijalankan secara acak. Keutamaan dari falsafah silih asih, silih asah, dan silih asuh merupakan satu kesatuan sikap, nilai, dan rukun hidup yang harus dijiwai oleh masyarakat dalam menjalakan kehidupannya demi terwujudnya masyarakat yang kuat, cerdas, egaliter berlandaskan pada rasa cinta dan kasih sayang antarsesama. Selain itu, konsep ini melambangkan keharmonisan hidup antara manusia dengan penciptanya, manusia dengan sesama, dan manusia dengan alam.

Silih asih yang berarti saling menebar cinta kasih atau rasa saling menyayangi. Silih asih merupakan salah satu bentuk ikhtiar interaksi manusia dengan Tuhan demi mendapat cinta kasih-Nya dengan cara menyayangi dan menebar cinta terhadap sesamanya. Semangat silih asih merupakan semangat membumikan nilai-nilai ketauhidan. Karena dalam budaya silih asih tertanam kuat prinsip ke-Tuhanan dan kemanusiaan. Dalam kehidupan di masyarakat Sindangkerta pola hidup silih asih dikembangkan dengan falsapah hidup "anu gede nyaah kanu leutik, anu leutik hormat kanu gede".

Pola ini menggambarkan terjadinya saling menghormati dan menghargai yang didasari oleh rasa cinta-kasih. Konsep anu gede nyaah kanu leutik mengandung makna bahwa orang yang sudah dewasa/ mapan baik secara sosial maupun ekonomi harus "mikanyaah" kepada orang yang masih kecil. Kata "mikanyaah" mengandung makna menyangi dengan penuh 
keiklasan tanpa ada rasa balas jasa. Selain itu, kata mikanyaah mengandung makna mau memberi atau berbagi dengan orang lain yang secara sosial atau pun ekonomi masih berada di bawahnya. Dengan dibangunnya konsep anu gede nyaah kanu leutik, keharmonisan antar sesama bisa tercipta. Pola hidup anu leutik hormat kanu gede merupakan konsep hidup yang menggambarkan orang yang masih kecil mau menghargai/ menghormati orang yang lebih besar baik secara sosial maupun ekonomi. Dari semangat ini, akan melahirkan kehidupan masyarakat yang adil, harmonis dan menjauhkan diri dari pola hidup anarkis.

Dengan menerapkan pola silih asih yang dilandasi oleh prinsip hidup "anu gede yaah kanu leutik, anu leutik hormat kanu gede" akan membentuk mental masyarakat yang menjunjung tinggi nilai-nilai persamaan. Masyarakat silih asih dalam prakteknya akan saling menghormati satu sama lain serta akan menjunjung tinggi nilai persamaan dengan tidak menganggap adanya kelas sosial. Dalam hal ini manusia memiliki kedudukan yang sama, dalam arti tidak ada yang dipandang sempurna dan tidak ada manusia yang seluruhnya cela.

Silih asah berarti saling memberi pengetahuan. Hal ini berati terjadi tukar menukar pengetahuan atau pengalaman. Melalui proses transfer pengetahuan, akan terjadi perubahan pengetahuan dari yang bersifat tacit ke explicit. Pengetahuan masyarakat yang masih bersifat tacit akan luntur bahkan menghilang apabila tidak disertai dengan proses pengembangan pengetahuan tersebut. Apabila pengetahuan yang bersifat tacit berkembang menjadi explicit akan terus tumbuh dan berkembang sejalan dengan berkembangnya ilmu pengetahuan, sosial, dan budaya. Oleh karena itu, pengembangan pengetahuan diperlukan kesadaran berbagai pihak untuk saling berbagi pengetahuan. Dalam manajemen pengetahuan, sebuah pengetahuan akan dialirkan dari pemilik pengetahuan kepada penerima pengetahuan. Arus pengetahuan yang terjadi dapat dianalisis menggunakan metode yang sering disebut siklus pengetahuan (Knowledge Flow). Siklus pengetahuan bisa dijadikan acuan dalam pelestarian, bahkan pengembangan suatu pengetahuan. Pola siklus pengetahuan dapat digambarkan dalam pola interaksi yang akan terus bergulir ketika pengetahuan tersebut dikemukakan kepada penerima pengetahuan. Proses ini merupakan gambar dari siklus pengetahuan.

Proses mengelola pengetahuan mengenai budaya Sunda yang dikelola oleh Saung Budaya Tatar Karang masih memiliki hambatan. Hambatan terbesar adalah masih adanya jurang pemisah antara budayawan, tokoh agama, dan masyarakat. Jurang pemisah ini terjadi karena perbedaan sudut pandang mengenai nilai-nilai budaya dan agama. Sebagai contoh pelaksanaan hajat lembur. Para tokoh budaya memandang bahwa pelaksanaan hajat lebur hanya sebagai ritual budaya untuk mempertahankan nilai-nilai seni dan budaya yang telah diterapkan oleh para leluhur kampung. Sedangkan para tokoh agama memandang bahwa dalam pelaksanaan hajat lembur ada unsur syirik. Oleh karena itu, untuk memadukan pandangan dari para tokoh agama dan tokoh budaya diperlukan mediator. Adanya mediator komunitas Saung Budaya Tatar Karang Cipatujah beberapa kesulitan dalam pengembangan literasi budaya bisa teratasi. Melalui kegiatan komunitas ini proses literasi budaya dilakukan melalui konsep manajemen pengetahuan yaitu tahap sosialisasi, eksternalisasi, kombinasi, dan internalisasi (Nonaka, 1998).

Melalui manajemen pengetahuan, pengetahuan yang dimiliki bisa ditransfer oleh pemilik pengetahuan kepada penerima pengetahuan. Dalam transfer pengetahuan ada yang dinamakan siklus pengetahuan. Siklus pengetahuan pertama kali dikenalkan oleh seorang ahli kimia bernama Polanyi. Polanyi membagi pengetahuan dalam dua jenis yaitu tacit knowledge dan explicit knowledge (Tobing, 2007). Dalam proses knowledge transfer mungkin saja ada beberapa hambatan yang dapat menghambat pengetahuan tersebut diterima oleh penerima pengetahuan. Menurut Sangkala (2007) hambatan terbesar dalam upaya organisasi melakukan knowledge transfer yaitu adanya kultur penghambat yang biasa disebut pertentangan (frictions). Pertentangan akan menghambat atau bahkan mencegah terjadinya 
proses knowledge transfer. Hal ini adanya ketidak sepahaman antara penerima pengetahuan dengan pemberi pengetahuan atau antar sesama penerima pengetahuan.

Proses literasi budaya di wilayah Tatar Karang dilaksanakan melalui orang yang memahami budaya kepada masyarakat (generasi muda) dengan konsep ngawanohkeun. Salah satu contoh proses ngawanohkeun adalah dengan menggelar permainan tradisional kaulinan barudak lembur. Pada pelaksanaan ngawanohkeun tidak ada unsur paksaan. Dalam proses ngawanohkeun anak tidak dipaksa untuk belajar atau pun ikut bermain. Dalam konteks ngawanohkeun anak-anak diundang untuk menyaksikan anak-anak lain yang sedang bermain. Prosesnya yakni anak-anak yang sudah biasa bermain diminta mendemontrasikan setiap permainan. Pada saat proses demonstrasi berlangsung, anak-anak lainnya cukup menonton pelaksanaan permainan tersebut. Melalui proses peragaan kaulinan barudak lembur maka anak-anak menjadi semakin mengenal "wanoh" terhadap setiap permainan.

Sering diperagakannya permainan ini, semakin banyak anak-anak yang tertarik untuk mempelajari bahkan ikut serta dalam permainan. Melalui proses ini maka anak-anak menjadi memiliki rasa resep 'suka" terhadap permainan ini. Setelah tumbuhnya rasa resep pada diri anak tersebut, mereka akan keyeng dalam berlatih sehingga mucullah anak-anak dengan bakat-bakat baru. Namun, kegiatan pelestarian ini tidak mungkin bisa berjalan baik apabila tidak dukungan "pangrojong" dari keluarga dan masyarakat. Dalam hal ini keluarga anak-anak yang sudah mulai memiliki rasa resep terhadap permainan anak-anak.

Sedangkan untuk mendapatkan dukungan "pangrojong" dari masyarakat sekitar yaitu masyarakat Desa Sindangkerta para pengelola Saung Budaya Tatar Karang Cipatujah menggunakan strategi anjang sono. Konsep anjang sono dipilih karena memiliki kelebihan yakni konsep ini penuh rasa cinta kasih dan kekeluargaan. Anjang sono mengandung arti berkunjung kepada kerabat dengan penuh cinta kasih. Pelaksanaan anjang sono bertujuan untuk memperkuat ikatan kekeluargaan.

Selain gambaran di atas, dalam proses silih asah terjadi pula proses internalisasi pengetahuan yang dilakukan yaitu konsep "belajar bersama sambil bermain". Ketika proses belajar bersama, anak-anak dilibatkan langsung dalam permainan kaulinan barudak lembur. Selain terlibat secara langsung dalam sebuah permainan, anak-anak ini diberi penjelasan mengenai proses bermain dan nilainilai yang terkandung di dalamnya. Dengan demikian, proses transfer pengetahuan dilakukan secara lisan dan tulisan sehingga terjadi proses kristalisasi dalam kegiatan pengelolaan pengetahuan Kaulinan barudak lembur di desa Cipatujah. Konsep kristalisasi ke dalam bentuk yang lebih konkrit diharapkan semua pengetahuan dapat digunakan dan dimanfaatkan oleh semua lapisan masyarakat. Kristalisasi merupakan bentuk pengubahan pengetahuan yang kegiatannya diistilahkan oleh Ikujiro Nonaka (1998) sebagai model konversi internalisasi.

Silih asuh mengandung makna membimbing, mengayomi, membina, menjaga, mengarahkan dengan seksama agar selamat lahir dan batin. Silih asuh dilaksanakan dengan cara saling mengingatkan, saling membangun kesadaran akan ilmu pengetahuan, dan saling mendukung dalam pengembangan diri sesamanya. Ini demi terbentuknya satu kesatuan masyarakat yang cerdas. Sebuah masyarakat yang cerdas merupakan satu syarat terbentuknya masyarakat yang kuat, tanpa kecerdasan dan kesadaran akan ilmu pengetahuan masyarakat akan kehilangan hakikat dan kemerdekaannya sebagai manusia sehingga tanpa ilmu pengetahuan masyarakat akan mudah untuk dibodohi, didiskriminasi dan dieksploitasi. Semangat silih asah merupakan semangat membangun dan menumbuhkembangkan khazanah keilmuan. Dalam masyarakat yang menjiwai rukun hidup silih asah, ilmu pengetahuan akan berdampingan dengan dimensi etis sehingga ilmu pengetahuan tidak lagi menjadi alat penindasan yang angkuh tetapi ilmu pengetahuan akan menjelma 
menjadi anggun yang akan membebaskan dan mengangkat derajat masyarakat dari keterbelakangan.

Setelah masyarakat menyadari akan persamaan, maka akan terbentuklah satu bangunan rasa saling menjaga yaitu silih asuh. Silih asuh (sikap saling memelihara) masyarakat, silih asuh pastilah akan membebaskan manusia dari batas-batas yang mampu membentuk masyarakat yang terkotakkotak. Semangat masyarakat akan saling menjaga tanpa memandang siapa. Seseorang yang telah menjalankan dan menjiwai falsafah silih asah tidak akan berbicara "saya", "dia" dan "mereka" tetapi dia akan berbicara "kita", oleh karena itu silih asah dapat membentuk rasa tanggung jawab serta membangun satu kesatuan masyarakat yang utuh, dapat dilihat pada gambar 2.

Falsafah silih asih, silih asah, silih asuh masih sangat relevan dalam kehidupan yang serba modern ini. Bahkan falsafah ini bisa menjadi solusi dalam membebaskan manusia dari belenggu penindasan, keterbelakangan, dan keterasingan.

\section{E. KESIMPULAN}

Proses literasi budaya yang dikembangkan di daerah Sindangkerta berdasarkan kepada konsep silih asih, silih asah, dan silih asuh. Pelaksanaan ketiga konsep ini harus selalu berurutan. Ketiga konsep ini tidak bisa dijalankan secara acak dan sembarangan. Keutamaan dari falsafah silih asih, silih asah, dan silih asuh merupakan satu kesatuan sikap, nilai, dan rukun hidup yang harus dijiwai oleh masyarakat dalam menjalakan kehidupannya demi terwujudnya masyarakat yang kuat, cerdas, egaliter berlandaskan pada rasa cinta dan kasih sayang antarsesama. Silih asih dikembangkan dengan falsafah hidup "anu gede nyaah kanu leutik, anu leutik hormat kanu gede". Pola ini menggambarkan terjadinya saling menghormati dan menghargai yang didasari oleh rasa cinta-kasih. Silih asah berarti saling memberi pengetahuan. Hal ini berati terjadi tukar menukar pengetahuan atau pengalaman. Melalui proses transfer pengetahuan, akan terjadi perubahan pengetahuan dari yang bersifat tacit ke explicit. Proses literasi budaya dilaksanakan melalui orang yang memahami budaya kepada masyarakat (generasi muda) dengan konsep ngawanohkeun. Proses silih asah terjadi pula proses internalisasi pengetahuan yang dilakukan yaitu konsep "belajar bersama sambil bermain". Silih asuh dilaksanakan dengan cara saling mengingatkan, saling membangun kesadaran akan ilmu pengetahuan, dan saling mendukung dalam pengembangan diri sesamanya.

\section{DAFTAR PUSTAKA}

American Library Association. (1989). Presidential committee on information literacy. Retrieved April 4, 2018, from http://www.ala.org/acrl/ publications/ whitepapers/presidential $\% 3 \mathrm{E}$

Anwar, R. K, Rizal, E. \& Saepudin, E. (2015). Kemampuan literasi informasi siswa tentang apotek hidup berbasis individual competence framework (studi terhadap siswa SMA di kota Bandung). Kajian Ilmu Informasi \& Perpustakaan, 3(1), 9-32.

Ati, S. (2015). Analisis literasi informasi pemakai taman bacaan masyarakat. Kajian Ilmu Informasi \& Perpustakaan, 3(1), 89-100.

Bahtar, M.A \& Sasmita, A. (2009). Literasi informasi tenaga pendidik dan kependidikan Pendidikan Non Forma (PNF) di Provinsi DKI Jakarta. Baca, 30(2).

Creswell, J. W. (2014). Penelitian kualitatif \& desain riset. Yogyakarta: Pustaka Pelajar.

Kementrian Pendidikan dan Kebudayaan. (2017). Literasi budaya dan kewargaan. $\mathrm{J}$ a k a r t a. R e t ri e v e d f r o m http://gln.kemdikbud.go.id/glnsite/wpcontent/uploads/2017/10/1iterasiBUDAYA-DAN-KEWARGAAN.pdf

Khadijah, U. L. S. (2016). Literasi informasi motivasi berwirausaha ibu rumah tangga kelurahan nagasari kabupaten Karawang Barat. Jurnal Kajian Ilmu Informasi dan Perpustakaan, 4(2), 150. Retrieved from http://jurnal.unpad.ac.id/jkip/article/view/8 $491 / 4796$ 
Kusumadara, A. (2011). Pemeliharaan dan pelestarian pengetahuan tradisional dan ekspresi budaya tradisional Indonesia: Perlindungan hak kekayaan intelektual dan non-hak kekayaan intelektual. Hukum IUS QUIA IUSTUM, 18(1), 20-41.

Mulyana, D. (2007). Metode penelitian kualitatif. Bandung: Remadja Rosdakarya.

Nonaka, I. (1998). The concept of "Ba" building a foundation for knowledge creation. California Management Review, 4(3), 40-54.

Sangkala. (2007). Knowledge management. Jakarta: Raja Grafindo Persada.

Sudarsono, A. N. (1997). Kearifan lingkungan: Dalam perspektif budaya Jawa. Jakarta: Obor Indonesia.
Sugiyono. (2010). Metode penelitian pendidikan. Bandung: Alfabeta.

Tobing, P. L. (2007). Konsep knowledge management, konsep, arsitektur dan implementasi. Grha Ilmu.

Widja, I. G. (1993). Pelestarian budaya: Makna dan Implikasinya dalam proses regenerasi bangsa (kebudayaan). Denpasar: Upada Sastra.

Yudistira, Y. (2015). Literasi informasi pustakawan di perpustakaan Fakultas Teknik UGM menggunakan pengembangan model the BIG6. Berkala Ilmu Perpustakaan dan Informasi, 13(1), 97-106. 


\section{DAFTAR GAMBAR}

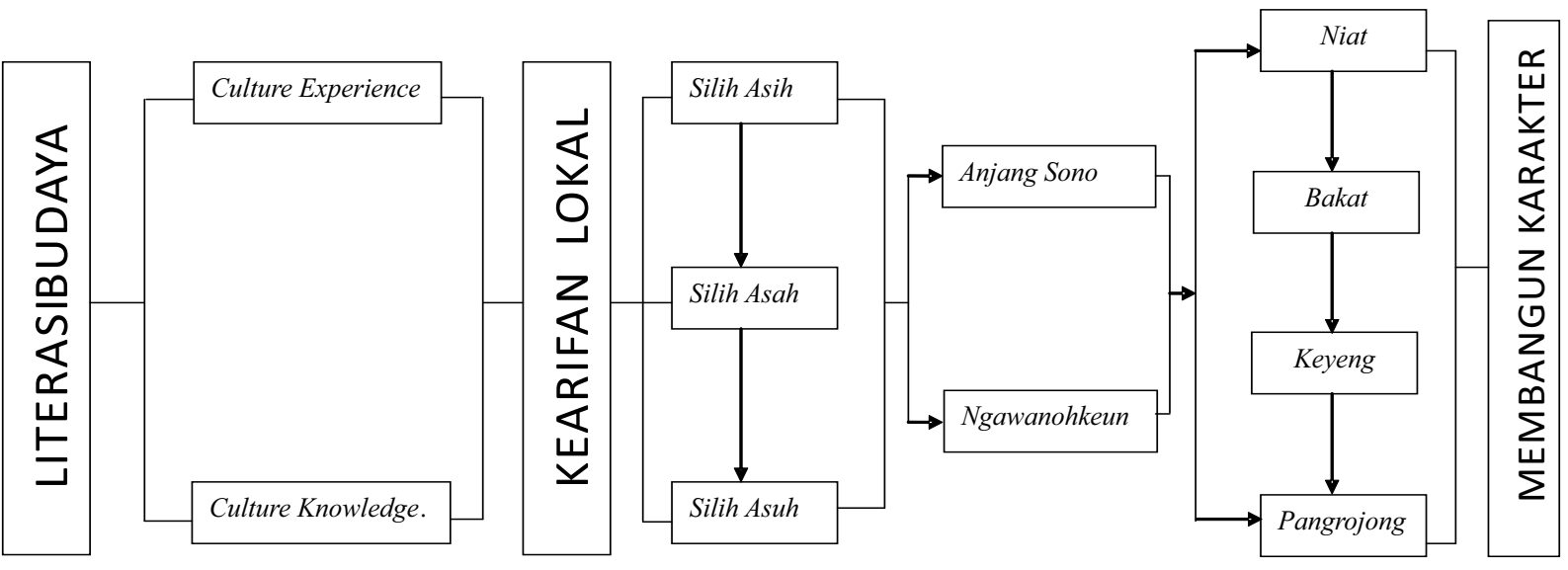

Gambar 1. Model literasi budaya berdasarkan hasil penelitian

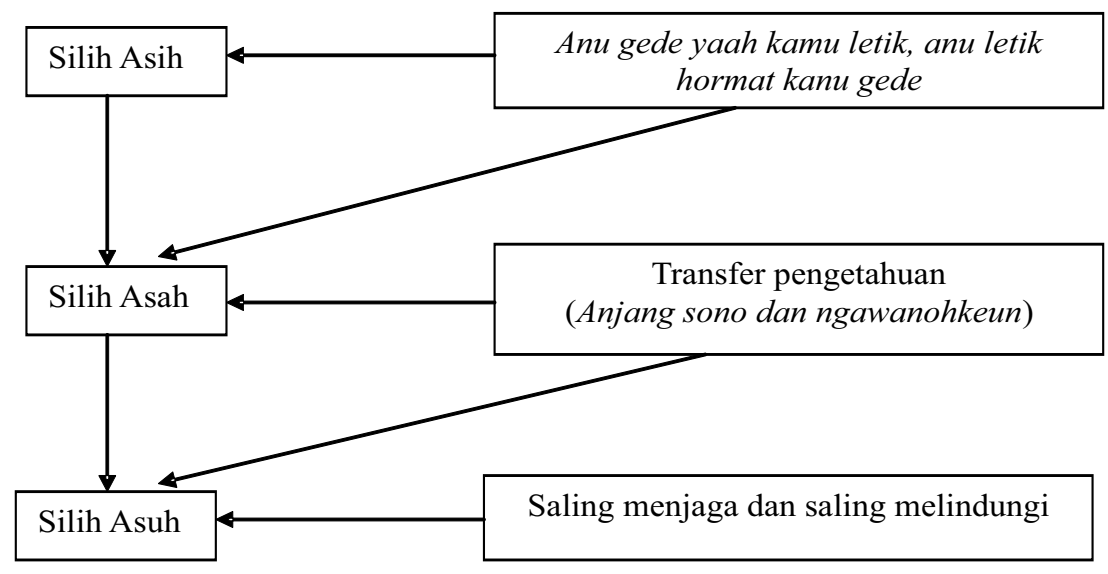

Gambar 2. Pola pengembangan literasi budaya berdasarkan hasil penelitian 